\title{
The Improvement of Drinking Water Access in Developing Countries: Case Study of 10 Countries in South-East Asia
}

\author{
Agustyarum Pradiska Budi ${ }^{1}$, Mugi Raharjo ${ }^{2}$, Evi Gravitiani ${ }^{3}$ \\ \{agustyarum.pradiska@gmail.com ${ }^{1}$, e_gravity2000@yahoo.com ${ }^{3}$ \} \\ Universitas Sebelas Maret, Indonesia
}

\begin{abstract}
This article examines the impact of sanitation improvement, economic growth, and the increasing of human development index on improving access to drinking water in developing countries (10 South-East Asia countries) from 2000 to 2015. and analyzed using panel analysis and multiple linear regression. The findings of this study is the variables of sanitation improvement and HDI improvement positively and significantly affect the improving of drinking water access . In addition, sanitation improvement specifically variables affect Bhutan and Nepal to improve access to safe drinking water, while the GDP and HDI do not have impact. While the three independent variables do not affect dependent variable in Bangladesh. This study reveals that the improving access to drinking water is affected by improved sanitation and increased HDI, but improved access to drinking water is not affected by economic growth.
\end{abstract}

Keywords: Sanitation, economic growth, human development index (hdi), and improved access to drinking water.

\section{Introduction}

Water is a basic needs for living things. Living things on the earth depend on water. But, the issues that occur lately threaten the sustainability of water resources. The impacts of climate are affect on various parts of the world. Earth's temperature is increase frequently and extremely. In addition to extreme climate change issues, there are also issues of access to clean water. Competing with climate change, the access to clean water is also an important issue considering that $70 \%$ of the water on earth can be consumed and not polluted.

The WHO report in "Progress on drinking water, sanitation and hygiene: 2017" stated that in 2015 a total of $89 \%$ of the global population was still in the deprivation stage and even still used basic drinking water services. The basic drinking water source in the WHO criteria is an improved source within 30 minutes of commuting to collect water. Patunru (2015) examined the variation of clean drinking water sources at the household level with the possibility of diarrhea outbreaks in a village using Susenas data in 2007 and 2011 in Indonesia. The conclusions in this study indicate that increasing access to clean water in Indonesia will be achieved in 2020 and conditional on increasing access to improved sanitation. Increasing access of improved sanitation is an aspect of complement to access to clean water. Based on the findings in this study, Patunhuru suggested that the high rate of diarrhea was associated with a stronger magnitude with poor environmental sanitation compared to low access to water. 
UNDP (United Nations Development Program) stated nearly 1,000 children died of diseases that could be prevented by water and sanitation. Access to drinking water and sanitation has a close relationship. Therefore, if access to drinking water has improved, it will be in line with improving access to sanitation. UNICEF in 2012 globally reported that the low quality of drinking water has led to an increase in the probability of the death of infants under 5 years of age at nearly 1.3 million people per year. Clean water and sanitation have a strong influence on the health of the population.

Inequality in national income and the low achievement of the human development index (HDI) between countries in Southeast Asia are presumed to be the cause of water access inequality. Gross Domestic Product (GDP) is an indicator that can be used to look at the economic conditions in a country. Improving the country's economic conditions is expected to be able to support public access to safe and affordable drinking water. The value of GDP consists of consumption, investment, government expenditure, exports and imports. The GDP component can be used to see how to manage government funds in building infrastructure related to improving access to drinking water.

Bogale and Urgessa, (2012) conducted a research on willingness to pay from rural households on improved water services in Haramaya, Ethiopia. Data were analyzed using dichotomous choice methods and bivariate probit models. The study shows that the amount of household in paying for water repair services is 27.30 cents per 20 liters. Household income, education, gender, water quality affect community participation in obtaining improved water services. The determinants of community participation can be represented by the value of HDI in a country.

Improving basic drinking water services into safe drinking water services is our shared need, so it is not only the responsibility of the government. Improving public access to drinking water requires community participation. The importance of community participation is needed to be able to support the government in accelerating access to safe and managed drinking water. The role and awareness of the community to participate is to see how the human development index in a country.

The value of HDI is one of the development targets of human development in a country. Components for measuring the value of HDI include a comparison of literacy rates, life expectancy, education and living standards. This component is useful in increasing access to safe and affordable drinking water, because each individual has improved in terms of living standards and education.

One of the goals of sustainable development is to ensure access to safe and affordable drinking water by 2030. In realizing this goal, the government's efforts can be done by investing in adequate infrastructure, providing sanitation facilities and encouraging each level. Therefore, access to drinking water is closely related to good economic growth. The scarcity of water is considered to be the cause and effect of poverty revealed by Cook, Fisher, Andersson, Rubiano, \& Giordano in 2009.

Access to clean and safe water is part of development and as a basic service that greatly affect a country's economic progress and low public health is particularly developing countries. Abebaw et al (2010) stated that development as an integration of economic growth, social, cultural and political conditions. The developing countries in Southeast Asia are one of reason for the backwardness of the country because of the lack of effective and sustainable use of available natural and human resources (Wendimu and Bekele, 2011).

Table 1. Data population of drinking water access in 2015 


\begin{tabular}{ccc}
\hline Country & $\begin{array}{c}\text { Safely Managed } \\
\text { Drinking Water }\end{array}$ & $\begin{array}{c}\text { Basic Drinking } \\
\text { Water }\end{array}$ \\
\hline Bangladesh & 56 & 97 \\
Bhutan & 34 & 98 \\
India & & 88 \\
Indonesia & & 90 \\
Maldives & & 98 \\
Myanmar & & 68 \\
Nepal & 27 & 88 \\
Sri Lanka & & 92 \\
Thailand & & 98 \\
Timor-Leste & & 70 \\
\hline
\end{tabular}

There are only 3 from 10 countries classified by WHO that have have access to safe drinking water. The three countries consist of Bangladesh, Bhutan and Nepal and two of them are still under $50 \%$. It means that from the 10 South-East Asian countries the average population still uses access to basic drinking water.

Judging from the strategic conditions of the South-East Asia country which does not have complex water problems such as sub-Saharan African countries. In fact, $95 \%$ of the population from South-East Asia countries still use basic drinking water services. In the classification of Worldbank, 10 countries in South-East Asia as a country with lower middle income. Therefore, in this study will discuss how the effect of improved sanitation, GDP and HDI on improving access to drinking water during the period 2000-2015. This study took case studies in 10 countries in Southeast Asia. The GDP variable, improved sanitation, and HDI are able to represent the level of economic growth, health level, and level of inequality in access to drinking water. Another objective in this study is to see how the three independent variables affect the state with access to improved drinking water.

There are only 3 from 10 countries classified by WHO that have have access to safe drinking water. The three countries consist of Bangladesh, Bhutan and Nepal and two of them are still under $50 \%$. It means that from the 10 South-East Asian countries the average population still uses access to basic drinking water.

Judging from the strategic conditions of the South-East Asia country which does not have complex water problems such as sub-Saharan African countries. In fact, $95 \%$ of the population from South-East Asia countries still use basic drinking water services. In the classification of Worldbank, 10 countries in South-East Asia as a country with lower middle income. Therefore, in this study will discuss how the effect of improved sanitation, GDP and HDI on improving access to drinking water during the period 2000-2015. This study took case studies in 10 countries in Southeast Asia. The GDP variable, improved sanitation, and HDI are able to represent the level of economic growth, health level, and level of inequality in access to drinking water. Another objective in this study is to see how the three independent variables affect the state with access to improved drinking water.

\section{Research methods}

The study was conducted in 10 middle and lower income countries in South-East Asia. This article is a quantitative study using secondary data from 2000 to 2015 cover Bangladesh, 
Bhutan, India, Indonesia, Maldives, Myanmar, Nepal, Sri Lanka, Thailand and Timor-Leste. The data generate from WHO, Worldbank and United Nations Development Reports.

Table 2. Specification of variables

\begin{tabular}{|c|c|c|c|}
\hline No & Variable & Variable Definition & Source \\
\hline 1 & $\begin{array}{l}\text { Population using at } \\
\text { least basic drinking- } \\
\text { water services (\%) }\end{array}$ & $\begin{array}{l}\text { The percentage of population using at least basic } \\
\text { drinking water services, that is, the population that } \\
\text { drinks water from an improved source, provided } \\
\text { collection time is not more than } 30 \text { minutes for a round } \\
\text { trip. This indicator encompasses both people using basic } \\
\text { drinking water services as well as those using safely } \\
\text { managed drinking water services. Improved water } \\
\text { sources include piped water, boreholes or tubewells, } \\
\text { protected dug wells, protected springs, and packaged or } \\
\text { delivered water }\end{array}$ & WHO \\
\hline 2 & $\begin{array}{lr}\text { Population } & \text { using } \\
\text { safely } & \text { managed } \\
\text { drinking } & \text { water } \\
\text { services }(\%) & \end{array}$ & $\begin{array}{l}\text { Population drinking water from an improved source that } \\
\text { is accessible on premises, available when needed and } \\
\text { free from faecal and priority chemical contamination. } \\
\text { Improved water sources include piped water, boreholes } \\
\text { or tubewells, protected dug wells, protected springs, and } \\
\text { packaged or delivered water }\end{array}$ & WHO \\
\hline 3 & $\begin{array}{l}\text { Gross Domestic } \\
\text { Product (GDP) }\end{array}$ & $\begin{array}{l}\text { GDP at purchaser's prices is the sum of gross value } \\
\text { added by all resident producers in the economy plus any } \\
\text { product taxes and minus any subsidies not included in } \\
\text { the value of the products. It is calculated without making } \\
\text { deductions for depreciation of fabricated assets or for } \\
\text { depletion and degradation of natural resources. Data are } \\
\text { in current U.S. dollars. Dollar figures for GDP are } \\
\text { converted from domestic currencies using single year } \\
\text { official exchange rates. For a few countries where the } \\
\text { official exchange rate does not reflect the rate effectively } \\
\text { applied to actual foreign exchange transactions, an } \\
\text { alternative conversion factor is used. }\end{array}$ & $\begin{array}{l}\text { Worldbank } \\
\text { Data }\end{array}$ \\
\hline 4 & $\begin{array}{l}\text { Human Development } \\
\text { Index (HDI) }\end{array}$ & $\begin{array}{l}\text { HDI classification is based on the intersection of HDI } \\
\text { generates from distribution quartile of indicator } \\
\text { component. The intersection is less than } 0,550 \text { for low } \\
\text { human development, } 0,550-0,699 \text { medium human } \\
\text { development, } 0,700-0,799 \text { high human development } \\
\text { and } 0,800 \text { or higher for high human development index. }\end{array}$ & $\begin{array}{l}\text { UNDP } \\
\text { Publications }\end{array}$ \\
\hline
\end{tabular}

This study employs panel data regression analysis and multiple linear regression. Panel data is obtained by combining time series and cross section data. The use of panel data regression analysis enable researchers to see the characteristics between time and between countries in variables that may vary. Panel data regression analysis has two stages, the first is to see the extent of the influence of the independent variables used to improve access to drinking water in 10 South-East Asian countries. The second stage panel data regression is used to see the picture of drinking water access conditions in each country with the influence of the same independent variable.

Estimation of the regression model using panel data in this study uses two approaches, including fixed effect and Random Effect model. Hausman test is utilized to determine the 
proper model. Hausman test is a statistical test to choose whether the Fixed Effect or Random Effect model is the most appropriate to use.

Multiple linear regression is utilized to determine the effect of each variable on a country with improved drinking water access. It aims to find out how strong independent variables can affect the dependent variable. Therefore, multiple linear regression is used followed by validity and reliability tests and passes the classical assumption test.

\section{Analysis and discussion}

This study presents two hypotheses, namely the influence of increasing access to basic drinking water in Southeast Asia and the influence factors on countries with improved water access. The subjects of this study were 10 developing countries in South-East Asia with the middle to lower income category. Some previous research are conducted on a micro scale, namely households. While this study utilize macro data where the unit of analysis lies at the level of a country during the period 2000-2015.

\subsection{The Determinants Drinking Water Improvement Access in South-East Asia}

Developing countries in general are countries with low average income levels, less developed infrastructure, and the human development index is below the global normal standard. This study employ 10 countries in South-East Asia as an example to see the effect of variables such as improving sanitation, GDP and HDI on improving access to drinking water from 2000 to 2015 in developing countries.

\subsubsection{Best Model Analysis}

Analysis of the panel data model is used in two approaches, namely the fixed effect approach and the random effect approach. The selection of this model using the best analysis test is fully explained in the following table 3 : 
Table 3. Best model analysis

\begin{tabular}{|c|c|c|}
\hline $\begin{array}{c}\text { Variabel Dependent } \\
\text { : Akses Driniking } \\
\text { Water }\end{array}$ & $\begin{array}{c}\text { Fixed Effect } \\
\text { Model (FEM) }\end{array}$ & $\begin{array}{c}\text { Random Effect } \\
\text { Model (REM) }\end{array}$ \\
\hline Konstanta & 4.565195 & -43.12546 \\
\hline Standard Error & 23.3177 & 19.45952 \\
\hline Probability & 0.845 & 0.027 \\
\hline Sanitation Access & 0.9574882 & 0.7104731 \\
\hline Standard Error & 0.0876067 & 0.0766433 \\
\hline Probability & 0.000 & 0.000 \\
\hline GDP & 4.594502 & 9.692986 \\
\hline Standard Error & 2.565449 & 2.231002 \\
\hline Probability & 0.075 & 0.000 \\
\hline HDI & 20.99011 & 16.07974 \\
\hline Standard Error & 7.043691 & 7.51841 \\
\hline Probability & 0.003 & 0.032 \\
\hline $\mathbf{R}^{\mathbf{2}}$ & 0.0753 & 0.2199 \\
\hline F Stat Probability & 0.0000 & 0.0000 \\
\hline
\end{tabular}

The selection of panel data method is done on all sample data. Thus, Hausman test is utilized to choose between the Fixed Effect or Random Effect method. Hausman test is a test to determine the use of the method between Random Effect and Fixed Effect. If the results of the Hausman Test accept the null hypothesis, the best model to use is the Random Effect model. However, if the result states reject the null hypothesis, the best model used is the Fixed Effect model.

Table 4. Hausman test

\begin{tabular}{|c|c|c|}
\hline Test Summary & Chi (2) & Prob. \\
\hline Cross-Section Random & 11.44 & 0.0434 \\
\hline
\end{tabular}

Based on the Hausman Test table, the value of the random Cross-section probability is 0.0434 which is smaller than Alpha 0.05, thus rejecting the null hypothesis. According to the Hausman test, the best model used is a model using the Fixed Effect method.

\subsubsection{Data Panel Model Estimation Results}

Based on the analysis of the best model and the Hausman test that has been done, the regression model used is Fixed Effect Model. Fixed Effect Model is a panel data estimation technique that expected to have no correlation between individual variables of the entity. The following table shows the results of data estimation with the number of observations as many as 10 countries from 2000 to 2015 (15 years). 
Table 5. Panel analysis, fixed effect model

\begin{tabular}{|l|l|}
\hline $\begin{array}{l}\text { Variabel Dependent : Drinking } \\
\text { Water Acsess }\end{array}$ & Fixed Effect Model (FEM) \\
\hline Konstanta & 4.565195 \\
\hline Standard Error & 23.3177 \\
\hline Probabilitas & 0.845 \\
\hline Sn = Perbaikan Akses Sanitasi & 0.9574882 \\
\hline Standard Error & 0.0876067 \\
\hline Probabilitas & 0.000 \\
\hline Loggdp = GDP & 4.594502 \\
\hline Standard Error & 2.565449 \\
\hline Probabilitas & 0.075 \\
\hline Hdi = HDI & 20.99011 \\
\hline Standard Error & 7.043691 \\
\hline Probabilitas & 0.003 \\
\hline $\mathbf{R}^{\mathbf{2}}$ & 0.0753 \\
\hline Probabilitas F Stat & 0.0000 \\
\hline
\end{tabular}

Based on the estimation above (using the fixed effect approach), a panel data analysis model constructed on the determinants of improvement of access to drinking water in 10 countries in South-East Asia which are interpreted as follows:

$$
\text { DW }=\beta_{0}+\beta_{1} * \mathrm{SN}+\beta_{2} * \text { LOGGDP }-\beta_{3} * \mathrm{HDI}+\text { et }
$$

The panel data equation model is as follows :

$$
\begin{aligned}
& Y_{i t}=\beta 0+\beta 1 X 1 \text { it }+\beta_{2} X 2_{i t}+\beta_{3} X 3_{i t}+\varepsilon \\
& Y_{i t}=4.565195+0.9574882 X 1+4.594502 X 2+20.99011 X 3+\text { et }
\end{aligned}
$$

The results of the panel analysis show that improved sanitation and HDI affect the improvement of access to drinking water, but GDP does not affect the drinking water access improvement.

It can be interpreted that every $1 \%$ increase in sanitation improvements will increase $95 \%$ improvement in access to drinking water. This is in line with what was revealed by UNDP that improving access to drinking water has a close relationship to improving sanitation access. Patunhuru's (2015) stated that increasing access to clean water is conditional on increasing access to improved sanitation because of the influence of population health. This result is in line with previous research by UNICEF (2012), Bogale and Urgessa (2012) and Patunhuru (2015).

The second variable is GDP (Gross Domestic Product) that the representative of economic growth. The results show that there is no influence between GDP and improved access to drinking water. If economic growth has no effect on improving access to drinking water, this is contrary to the role of the government in achieving sustainable development (SDGs) by ensuring access to safe and affordable drinking water by 2030 . That is, increasing access to drinking water still depends only on one party namely by relying on community participation but the government did not participate directly in pushing for these improvements. Abebaw et al (2010) argues that development is an integration of economic growth, social, cultural and political conditions. The failure of the integration of these three things is partly due to the lack of role of 
economic growth in improving access to drinking water such as infrastructure provision, so that the level of development in South-East Asia is in the low / developing category.

Another weakness of developing countries is the human development index which is under the normal global standard. This study uses WHO standards in viewing HDI. The HDI classification by WHO is HDI $<0.550$ for low human development, HDI is between 0.550 0.699 for moderate human development, and HDI is between $0.700-0.799$ for high human development, and HDI is 0.800 for very high human development.

in 10 countries South-East Asia have HDI below 0.550 so they fall into the low HDI category. The finding in this study is that $1 \%$ increase in HDI will increase the improvement of access to drinking water by $20,99011 \%$. This is in line with the opinion of Bolage and Urgessa (2012) where social conditions are very influential on improving water services. The social condition of the community is reflected in the components of the human development index including life expectancy, education and decent living standards.

\subsubsection{Statistic Test}

Statistical tests in this study include determination $\left(\mathrm{R}^{2}\right)$, significance test together (Test Statistics F) and the significance of individual parameters test (Test Statistics t).

Table 6. Determination coefficient $\left(\mathrm{r}^{2}\right)$ and data panel $\mathrm{f}$ test

\begin{tabular}{|l|l|}
\hline $\begin{array}{l}\text { Coefficient Determination } \\
\left(\mathrm{R}^{2}\right)\end{array}$ & 0.0753 \\
\hline $\mathrm{Uji} \mathrm{F}$ & 0.0000 \\
\hline
\end{tabular}

The results of the data variable for improving sanitation, GDP, and HDI for improving access to drinking water in South-East Asia from 2000 to 2015 show the $\mathrm{R}^{2}$ of 0.0753 . It shows that statistically $7.53 \%$ of independent variables are able to explain the dependent variable. While the remaining $92.47 \%$ is affected by other variables.

The $\mathrm{F}$ test is used to determine the relationship between the independent variables as a whole and those obtained, namely improved sanitation, GDP, and HDI to improve access to drinking water in South-East Asia. From the results of the data processing, it is known that the F-statistical probability value is 0.0000 (significant at $5 \%$ ). It means that the independent variables simultaneously affect the dependent variable.

Table 7. Test of individual parameter significance ( $\mathrm{t}$ test)

\begin{tabular}{|l|c|c|c|}
\hline Variable & Uji T & Prob & Sig 5\% \\
\hline Sn & 10.93 & 0.000 & Signifikan \\
\hline Loggdp & 1.79 & 0.075 & Tidak Signifikan \\
\hline HDI & 2.98 & 0.003 & Signifikan \\
\hline
\end{tabular}

Sanitation and HDI improvement variables have $t$ values of 10.93 and 2.98 with probability values of 0.000 and 0.003 and smaller than 0.05 or $\alpha=5 \%$. It means that sanitation and HDI 
improvement variables have a positive and significant impact on improving access to drinking water in South-East Asia. While the GDP variable has t value of 1.79 with a probability value of 0.075 and greater than 0.05 , meaning that the GDP variable has no effect and is not significant on improving access to drinking water.

\subsection{The Determinants of State with Improved Drinking Water Access}

Access to drinking water in developing countries or countries with lower middle income as in countries in South-East Asia are still classified as having access to basic drinking water. In the background above it has been explained that there are only 3 countries using improved drinking water access and are still below $50 \%$ of the population. The three countries are Bangladesh, Bhutan and Nepal.

In this section we will discuss how sanitation, GPD and PDI variables can affect access to drinking water in countries that already have access to improved drinking water (just managed safely). It aims to compare between populations that use access to basic drinking water and access to drinking water that is safely managed in developing countries, it is necessary to analyze the three countries that have used access to safe drinking water.

Table 10. Multiple linear regression results

\begin{tabular}{l|c|c|c|c|c|c|c|c|c}
\hline \multirow{2}{*}{ Variable } & \multicolumn{3}{c}{ Bangladesh } & \multicolumn{4}{c}{ Bhutan } & \multicolumn{4}{c}{ Nepal } \\
\cline { 2 - 10 } & Coef & Uji T & $\mathbf{P}>|\mathbf{t}|$ & Coef & Uji T & P>|t| & Coef & Uji T & P>|t| \\
\hline Constant & 77.7773 & & & -11.91025 & & & 19.71887 & & \\
\hline SN & 0.3868 & 1.27 & 0.229 & 0.6514 & 2.56 & 0.025 & 0.2191 & 2.94 & 0.012 \\
\hline Loggdp & -5.7648 & -0.85 & 0.413 & 0.5702 & 0.26 & 0.872 & 1.8279 & 1.78 & 0.101 \\
\hline HDI & 64.5347 & 0.74 & 0.476 & -0.2373 & -0.24 & 0.812 & -58.5962 & -1.94 & 0.077 \\
\hline
\end{tabular}

The value of the regression coefficient of each variable can be written into the multiple linear regression equation as follows:

$$
\mathrm{Y}_{\mathrm{it}}=77.7773+0.3868 \mathrm{SN}-5.7648 \operatorname{Loggdp}+64.5347 \mathrm{HDI}+\mathrm{et}
$$

The value of the regression coefficient of each variable can be written into the multiple linear regression equation as follows:

$$
\mathrm{Y}_{\mathrm{it}}=77.7773+0.3868 \mathrm{SN}-5.7648 \operatorname{Loggdp}+64.5347 \mathrm{HDI}+\text { et }
$$

Bangladesh's constant value is 77.7773 meaning that without the effect of improving sanitation, GDP and HDI, the value of improving access to drinking water is 77.7773 . The constant value is quite large before it is influenced by both positive sanitation and HDI improvement variables, while GDP is negative. Regression probability values of the three variables were greater than 0.05 (Probability SN, LogGDP, HDI > 0.05), so these three variables did not have a significant effect on improving access to drinking water in Bangladesh.

$$
\mathrm{Y}_{\mathrm{it}}=-11.91025+0.6514 \mathrm{SN}+0.5702 \operatorname{Loggdp}-0.2373 \mathrm{HDI}+\mathrm{et}
$$


Bhutan's constant value of -11.91025 means that without the influence of improved sanitation, GDP and HDI, the value of improving access to drinking water in Bhutan is only 11.91025. The minus sign on the constant means the value of improving access to drinking water before being affected by improved sanitation and the value of GDP is very small. While the sign of the coefficient on the HDI variable has a negative coefficient sign, so it will give a decrease effect. However, the other two variables have a positive coefficient so that with the influence of the two variables, sanitation improvements will increase.

$$
\mathrm{Y}_{\mathrm{it}}=19.71887+0.2191 \mathrm{SN}+1.8279 \operatorname{Loggdp}-58.5962 \mathrm{HDI}+\text { et }
$$

Nepal linear regression estimation results have a constant value of 19.71887 , meaning that without the influence of independent variables (SN, LogGDP, and HDI) the value of improving drinking water access is 19.71 . Both SN and GDP variables have a positive sign, so they will have a positive influence on improving access to drinking water. HDI variable has a negative sign, it will give a decrease effect on improving access to drinking water.

Regression coefficient value of sanitation improvement variable $(\mathrm{SN})$ is 21.91 and probability value is $<0.05$. This means that $1 \%$ increase in sanitation improvements will increase the improvement of drinking water access by $21.91 \%$. The regression coefficient value of the GDP variable is 18.27 and the probability value> 0.05 , so the GDP (Loggdp) variable has no effect on improving access to drinking water in Bhutan. The regression coefficient value of the HDI variable is -58.59 and the probability value $>0.05$, meaning that the HDI variable cannot affect the improvement of access to drinking water.

Table 13. F tests and r square multiple linear regression

\begin{tabular}{|l|l|l|}
\hline Country & Uji F & R Square \\
\hline Bangladesh & 0.0000 & 0.9580 \\
\hline Bhutan & 0.0000 & 0.9703 \\
\hline Nepal & 0.0000 & 0.9296 \\
\hline
\end{tabular}

Table 11. shows that F Statistics on 3 multiple linear regression tests is 0.0000 (significance at $5 \%$ ), then F Statistics is smaller than alpha $(0.0000<0.05)$. This can mean that the independent variables (SN, GDP, and HDI) together influence the dependent variable in each country.

Table 11. shows that F Statistics on 3 multiple linear regression tests is 0.0000 (significance at $5 \%$ ), then F Statistics is smaller than alpha $(0.0000<0.05)$. This can mean that the independent variables (SN, GDP, and HDI) together influence the dependent variable in each country.

The results of the data from the improvement of sanitation, GDP and HDI on improving access to drinking water in 3 tests in 2000-2015 were obtained by $\mathrm{R}^{2}$ of 0.9580 (Bangladesh), 0.9703 (Bhutan), and 0.9296 (Nepal). This shows that statistically $95.80 \%$ of the independent variables were able to explain the dependent variable in Bangladesh, $97.03 \%$ of the independent variables were able to explain depenpen variables in Bhutan, and $92.96 \%$ of the dependent variables were able to be explained by independent variables. While the rest is influenced by other variables 


\section{Conclusion}

This study utilize multiple linear regression to analyse panel data and from 10 countries in South-East Asia. That are Bangladesh, Bhutan, India, Indonesia, Maldives, Myanmar, Nepal, Sri Lanka, Thailand, and Timor-Leste from 2000 to 2015. These countries are developing countries with lower middle income according to the World bank classification. In addition, from these 10 countries there are 3 countries with access to safely drinking water, so that the influence of the three variables will be compared to improving access to drinking water in each country.

The results revealed that the variables of improvement in sanitation (sn) and HDI had a positive and significant effect on improving access to drinking water. While the GDP variable do not significantly affect on improving access to drinking water. The effect of SN, GDP and HDI on improving access to safe drinking water in each country has different results. The finding from the analysis using multiple linear regression are: (1) the constant value of Bangladesh has reached 77.7773 without the influence of the independent variables and the three independent variables do not affect on the improvement of safe drinking water, (2) Bhutan has a very small constant value of -11.91025 where SN affect drinking water improvement access while GDP and HDI do not affect improving access to drinking water, (3) Nepal also has a low constant value of 19.71887 and only SN affect, while GDP and HDI do not affect.

In general, the population from 10 countries have is using basic drinking water access, so 2 variables (SN and HDI) have effect on improving drinking water and GDP does not affect. It shows that in developing countries, improved sanitation and increased HDI are closely related to improving access to drinking water. The value of GDP does not have a significant effect. In next studies, can use more specific variables to the component of GDP, such as government consumption.

Specifically, for each country with improved access to drinking water, sanitation improvement variables still have an effect, because it is in accordance with UNDP's statement that improving access to drinking water must be in line with improved sanitation, so that these variables are interrelated.

But the exception for a country with a percentage of more than $50 \%$ of the population has used access to safe drinking water, this is demonstrated by Bangladesh. The variables of GDP and HDI in each country do not have a significant effect on improving access to safe drinking water in these 3 countries, so in later studies can use more specific variables because the improvement of access to drinking water is greater supported by community participation compared to economic growth of a country. Increased economic growth is not followed by the use of government consumption in infrastructure development.

Acknowledgments. The author would like to thank Prof. Mugi Raharjo who has guided in writing this article. Thank you too for Dr. Evi Gravitiani, SE, M.Si who has provided valuable comments so that this article can be useful. 


\section{References}

[1] Abebaw et al (2010) in Mezgebo and Ewnetu.: Households willingness to pay for improved water sevices in urban areas : A case study from Nebelet town, Ethiopia. Journal of Development And Agricultural Economics. Vol. 7, Issued 1, pp. 12-19 (2015)

[2] ADB (Asian Development Bank).: Water In Asian Cities : Utilities' Performance and Civil Society Views. Manila : Asian Development Bank (2004)

[3] Basuki, Tri Agus and Yuliadi, Imamudin.: Electronic Data Processing (SPSS 15 and Eviews 7). Danisa Media : Yogyakarta. (2015)

[4] Bogale and Urgessa.: Households' Willingness to Pay for Improved Rural Water Service Provision : Application of Contingent Valuation Method in Eastern Ethipia. Journal of Human Ecology, Vol. 38, Issued 2, pp. 145-154 (2012)

[5] Chao Bao and Dongmei He.: The Causal Relationship between Urbanization, Economic Growth and Water Use Change in Provincial China. Sustainability 2015, Vol. 7, pp. 16076-16085 (2015)

[6] Data WHO Drinking Water Services, Receipt accssed on August, 2018 http://apps.who.int/gho/athena/data/GHO/WSH_WATER_SAFELY_MANAGED,WSH_WATER_B ASIC?filter=COUNTRY:*;RESIDENCEAREATYPE:*\&format=xml\&profile=excel.

[7] Data World Bank Growth Domestic Product (current US\$), accesed on August, 2018 http://data.worldbank.org/indicator/NY.GDP.MKTP.CD.

[8] Data UNDP Human Development Index, accssed on August, 2018.

[9] Josephine Tucker, Alan MacDonald, Lorraine Coulter, Roger C. Calow.: Household water use, poverty and seasonality: Wealth effects, labour constraints, and minimal consumption in Ethiopia. Water Resources and Rural Development, Vol. 3, pp. 27-47 (2014)

[10] Kamaludi, M., Sandran, K., Azlina, A.A., \& Radam, A.: Willingness to Pay for Improved Water Services in Kuala Terengganu. Jurnal Ekonomi Malaysia. Volume 51 (1), pp. 1007-118 (2017)

[11] Guha, S.: Valuation of Clean Water Supply by Willingness to Pay Method in a Developing Nation : A Case Study in Calcutta, India. Journal of Young Investigators, Volume 17, Issued 4 (2007)

[12] Gunatilake, H \& Tachiiri, M.: Willingness to Pay and Inclusive Tariff Designs for Improved Water Supply Services in Khulna, Bangladesh. ADB South Asia Working Paper Series, Issued 9 (2012) [13] Iffat Mahmud and Nkosinathi Mbuya.: Water, Sanitation, Hygiene, and Nutrition in Bangladesh, Can Building Toilets Affect Children's Growth?. Worldbank Study (2016)

[14] Motoshita, Itsubo, and Inaba.: Development of impact factors on damage to health by infectious diseases caused by domestic water scarcity. International Journal Life Cycle Assess, Volume 16, pp. 65-73 (2011)

[15] Ni Made Sukartini.: Accsess to Clean Water in Indonesia. Applied Quantitative Economic Journal. Vol. 9, No 2, pp. 89-98 (2016)

[16] Patunru, A.: Access to Safe Drinking Water and Sanitation in Indonesia. Asia \& The Pacific Policy Studies. Vol. 2, No 2, pp. 234-244 (2015)

[17] Rietveld,.P. Roundwendel, J,. \& Zwart, B.: Block rate pricing of water in Indonesia : An Analysis of Welfare Effects. Bulletin of Indonesia Economic Studies. Volume 36 (3), Pages : 73-92 (2000)

[18] Sattar, A \& Ahmad, E.: Willingness to Pay for the Quality of Drinking Water. Paistan Development Review, 4, pp. 767-777 (2007)

[19] Stanislaus S. Uyanto,Ph.D.: Guidence Analysis Data with SPSS, third Edition. Graha Ilmu : Yogyakarta (2009)

[20] WHO Report "Progress on drinking water, sanitation and hygiene: 2017, Update and SDG Baselines". WHO Publications.

[21] 